\title{
Behavior of 11 Organonitrogen Pesticides during the Refinement of Edible Oils
}

\author{
Toru Fukazawa $^{1 *}$, Yasuo Suzuki ${ }^{2}$, Shigeru TokaIrin ${ }^{2}$, Kenji Chimi ${ }^{1}$, \\ Takenori Maruyama ${ }^{1}$ and Teruyoshi Yanagita ${ }^{3}$ \\ ${ }^{1}$ Japan Institute of Oil \& Fats, Other Foods Inspection, Foundation \\ (3-27-8, Nihonbashi-Hamacho, Chuo-ku, Tokyo 103-0007, JAPAN) \\ ${ }^{2}$ Tsukishima Foods Industry Co., Ltd \\ (3-17-8, Higashi-Kasai, Edogawa-ku, Tokyo 134-8520, JAPAN) \\ ${ }^{3}$ Department of Applied Biological Sciences, Saga University \\ (1 Honjo, Saga 840-8502, JAPAN)
}

Edited by Y. Takizawa, Tokyo Gakugei Univ., and accepted April 5, 2005 (received for review February 4, 2005)

\begin{abstract}
Eleven organonitrogen pesticides (EPTC, chlorpropham, alachlor, metolachlor, thiobencarb, diethofencarb, pendimethalin, flutolanil, lenacil, fenarimol and bitertanol) were added to crude soybean oil, which was refined through degumming, alkali refining, bleaching and deodorization. The amounts of residual pesticides in the treated oils were determined immediately after each process.

DEGUMMING : Bitertanol and fenarimol were significantly decreased by $\mathrm{H}_{3} \mathrm{PO}_{4}$ treatment, but the other pesticides were not. With hot water treatment, all the pesticides remained at a level of $85 \%$ or more.

ALKALI REFINING : About $50 \%$ of lenacil was removed by both the $125 \% \mathrm{NaOH}$ and $200 \% \mathrm{NaOH}$ treatments. Removal rates of the other pesticides ranged from 15 to $20 \%$ for $125 \%$ $\mathrm{NaOH}$ and from 20 to $30 \%$ for $200 \% \mathrm{NaOH}$ treatments, respectively.

BLEACHING : More than $90 \%$ of bitertanol and fenarimol were efficiently removed by both the activated clay and activated clay containing activated charcoal. On the contrary, chlorpropham, thiobencarb and pendimetharin were decreased by less than $10 \%$.

DEODORIZATION : About half of fenarimol and bitertanol, and more than $80 \%$ of lenacil and flutolanil remaind after treatment at $260^{\circ} \mathrm{C}$ while the other pesticides decreased to below quantification limits.

We found that while each pesticide was decreased at a different rate, and each process decreased these pesticides differently, they could all ultimately be decreased through the 4 refining processes.
\end{abstract}

Key words: organonitrogen pesticide, refining process, edible oil, pesticide residue, GC/MS

\section{1 緒言 \\ 平成 13 年から 14 年にかけて, わが国で無登録農薬 が違法に輸入，販売，使用され，また中国産冷凍ほう れん草から残留基準值を超える農薬が検出され，大問}

題となった。日本国内の農作物への農薬の使用は，農 薬取締法により厳しく管理されているが，世界には約 700 種類の農薬が存在するといわれている現状では, 輸 入相手国の農薬の使用実態を把握することは困難であ る。油糧種子の大部分は輸入に頼って扣り，農薬が油

\footnotetext{
${ }^{*}$ Correspondence to: Toru FuKaZawa, Japan Institute of Oil \& Fats, Other Foods Inspection, Foundation, 3-27-8, Nihonbashi-Hamacho, Chuoku, Tokyo 103-0007, JAPAN

E-mail: fukazawa@syken.or.jp
} 
糧種子に残留した場合，搾油後の油脂に移行すること が懸念される。さらに，食品産業ではHACCP（Hazard Analysis and Critical Control Point）システムによる衛生 管理が導入され，食品の安全性を科学的及び体系的に 保障する時代になった（1）。著者らはこれまで有機塩 素系（2）, 有機リン系（3）及びピレスロイド系（4) の主要な農薬について, 食用油脂の精製工程に打ける 挙動を検討し, 原油中の有機塩素系及び有機リン系農 薬は，精製処理により除去されるが，ピレスロイド系 農薬の大部分は，精製油に残存しうることを報告した。 しかしながら，ピレスロイド系農薬は，水素添加工程 中に油脂から除去される（5）。今回は油糧作物に除草 剂, 殺菌剤として使用されている含窒素系農薬で残留 基準のある 11 種類を取り上げ, 食用油脂の精製工程に おける挙動を検討した。

\section{2 実験}

$2 \cdot 1$ 試 料

今回の実験で使用した含窒素系農薬は, EPTC, メト ラクロール, チオベンカルブ, ジェトフェンカルブ, ペンディメタリン，フルトラニル，レナシル（以上和 光純薬工業株式会社より購入), アラクロール, ビテル タノール，フェナリモル（以上林純薬工業株式会社よ り購入) , クロルプロファム (GLサイエンス株式会社 より購入) である。油脂は月島食品工業株式会社から 提供された大豆原油を用いた。この大豆原油からはこ れら 11 種類の含窒素系農薬は検出されなかった。

\section{$2 \cdot 2$ 精製工程及び農薬の添加量}

精製工程は Fig. 1 に示した。脱ガム, 脱酸, 脱色及 び脱臭の処理条件は, 前報 $(3,4)$ と同様に行った。各 工程に打ける農薬の挙動は, 原油, 脱力゙ム油, 脱酸油 及び脱色油ごとに農薬を添加して, 原油, 精製後の油 脂（脱ガム油, 脱酸油及び脱臭油）並びに副産物（ガ ム質, アルカリフーツ, 洗浄水, 廃白土及び脱臭スカ ム）について農薬を分析した。農薬の添加量は，前報 $(3,4)$ と同様に $5 \mathrm{ppm}$ とした。この添加量は, 油脂含 有率が $20 \sim 40 \%$ の油糧種子に含窒素系農薬の一般的な 残留基準值である 1.0 〜 $2.0 \mathrm{ppm}$ 含まれた場合に相当す る。

\section{$2 \cdot 3$ 分析方法}

含窒素系農薬の分析は, 抽出及び精製操作は衛生試 験法（6）に準じ，定量は質量分析で行った。油脂の場 合は, 試料 $3 \mathrm{~g}$ をへキサン $30 \mathrm{~mL}$ に溶解してへキサン 飽和アセトニトリル $30 \mathrm{~mL}$ で 3 回液一液分配した後, そ のアセトニトリル抽出液を濃縮して, ヘキサンに再溶
解した。次いでフロリジルカラムで精製した。操作は 次のように行った。クロマト管（内径 $15 \mathrm{~mm}$ ）に活性 化したフロリジル $5 \mathrm{~g}$ をへキサンで湿式充てんし，さら に無水硫酸ナトリウム約 $8 \mathrm{~g}$ を積層した。抽出液を負荷 し，ヘキサン $50 \mathrm{~mL}$ で洗浄した後， $20 \%$ アセトン含有 ヘキサン $200 \mathrm{~mL}$ で溶出した。この溶出液を減圧下 $\left(40^{\circ} \mathrm{C}\right.$ 以下) で濃縮乾固した。残留物にアセトンを加え て定容し, GC/MS 試験溶液とした。

\section{$2 \cdot 4$ GC/MS (SIM) 測定条件}

ガスクロマトグラフ/質量分析計：GC 部 $6890 \mathrm{~N}$, MSD 部 5973 Network（Agilent Technologies 社製）

カラム：DB-5MS (Agilent Technologies 社製)，内 径 $0.25 \mathrm{~mm}$ ×長さ $30 \mathrm{~m}$ ×膜厚 $0.25 \mu \mathrm{m}$, カラム温度 : $50^{\circ} \mathrm{C}(2 \mathrm{~min})-20^{\circ} \mathrm{C} / \mathrm{min}-160^{\circ} \mathrm{C}-2{ }^{\circ} \mathrm{C} / \mathrm{min}-$ $195^{\circ} \mathrm{C}-10^{\circ} \mathrm{C} / \mathrm{min}-290^{\circ} \mathrm{C}(10 \mathrm{~min})$ 定流量モード, 注入口温度 : $250^{\circ} \mathrm{C}$, トランスファーライン温度 : $280^{\circ} \mathrm{C}$, イオン化室温度： $230^{\circ} \mathrm{C}$, 四重極温度： $150^{\circ} \mathrm{C}$,
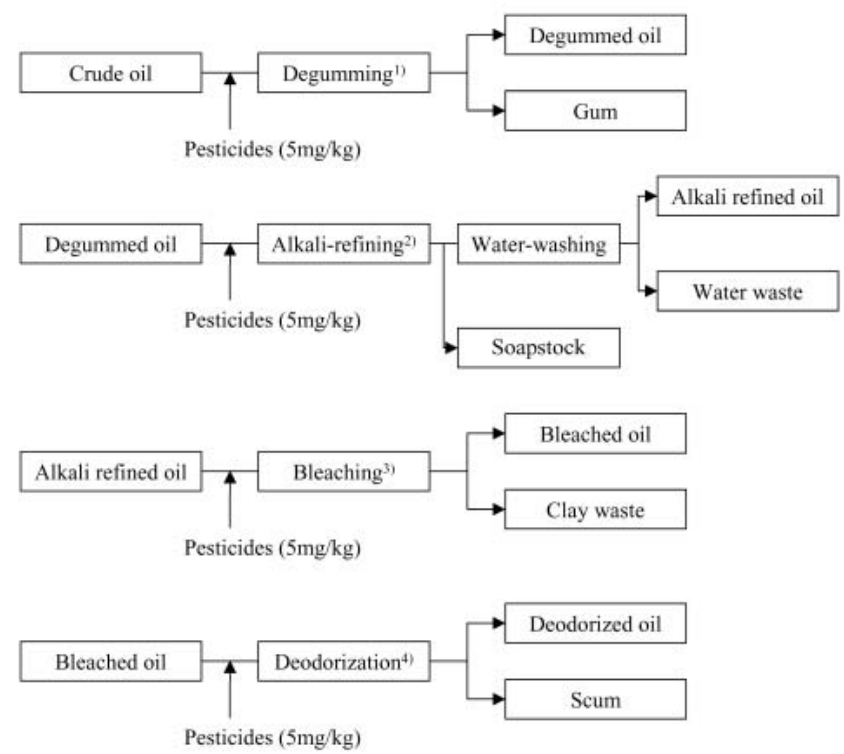

Fig. 1 Refining Conditions.

1) Degumming was done through use of $\mathrm{H}_{3} \mathrm{PO}_{4}(5$ $\mathrm{g} / \mathrm{kg})$ at $50^{\circ} \mathrm{C}$ or hot water $(15 \mathrm{~g} / \mathrm{kg})$ at $70^{\circ} \mathrm{C}$.

2) Alkali refining was done through use of $125 \%$ or $200 \%$ excess over requirements of $14 \%$ sodium hydroxide solution, which neutralizes free fatty acids in the degummed oil.

3) Bleaching was done through use of activated clay $(20 \mathrm{~g} / \mathrm{kg})$ or activated clay containing $20 \%$ activated charcoal $(20 \mathrm{~g} / \mathrm{kg})$.

4) Deodorization was done at 160,230 or $260^{\circ} \mathrm{C}$ for $1 \mathrm{~h}$ under a vacuum of $0.3 \mathrm{kPa}$ with $3 \%$ steam. 
注入方式：スプリットレス，注入量： $1 \mu \mathrm{L}$ ，測定モー ド : SIM

\section{3 結果および考察}

\section{$3 \cdot 1$ 添加回収実験}

大豆原油に各 $2 \mathrm{ppm} ，$ 精製油に各 $0.1 \mathrm{ppm}$ 添加し，回 収率及び定量限界を求めた。回収率はいずれも $90 \%$ 以 上であった。精製油を分析した場合の定量限界は， EPTC 及びクロルプロファムが 0.005 ppm，ジエトフェ ンカルブ及びペンディメタリンが $0.02 \mathrm{ppm}$ ，その他は $0.01 \mathrm{ppm}$ であった。

\section{$3 \cdot 2$ 脱ガム}

各工程における油脂及び副産物中の農薬は，分析結 果から油脂中の農薬残存率及び副産物への移行率を算 出して Table 1 に示した。農薬の残存率及び移行率は 添加量に対する割合（\%) で示した。
検討した 11 種類の農薬の残存率は, 温水処理 $\left(70^{\circ} \mathrm{C}\right)$ では $88.8 \sim 93.9 \%$ でほとんど除去されなかっ た。一方，リン酸処理 $\left(50^{\circ} \mathrm{C}\right)$ では，ビテルタノール， フェナリモル，レナシルの順で除去されやすく，残存 率はそれぞれ 3.7，26.1 及び 71.4\%であった。ビテルタ ノール, フェナリモル, レナシルの 3 農薬は, 酸性下 では水溶性を示すため, リン酸による脱ガム操作中に これらの一部が，ガム質に移行したものと考えられた。 そこで，ガム質を分析したところ，レナシルの移行率 は $25.2 \% て ゙$ 油脂から除去された相当量が検出された。 フェナリモルとビテルタノールの移行率はそれぞれ 7.0 及び $80.7 \%$ て部消失していることが観察された。

そこで，リン酸に対する農薬の安定性を調べた。各 農薬 $10 \mu \mathrm{g}$ をネジロガラス試験管に採り，85\%リン酸 5 $\mathrm{mL}$ を加えて密栓し，実際の処理温度の $50^{\circ} \mathrm{C}$ で保持し た。次いで 10,30 及び 60 分後の農薬の残存率を調べ, 結果を Fig. 2 に示した。アラクロール，ビテルタノー ル及びフェナリモルは処理時間が経過するにつれ残存

Table 1 Residual and Transfer rates of Organonitrogen Pesticides in Treated oils and the Residues during the Refining Process.

\begin{tabular}{|c|c|c|c|c|c|c|c|c|c|c|c|c|c|}
\hline \multirow{2}{*}{$\begin{array}{l}\text { Process } \\
\text { (Added amount } \\
\text { of pesticides) }\end{array}$} & \multirow{2}{*}{$\begin{array}{l}\text { Process }^{1)} \\
\text { condition }\end{array}$} & \multicolumn{12}{|c|}{ Residual and tranfer rate (\%) } \\
\hline & & $\begin{array}{l}\text { Treated oil } \\
\text { and resudue }\end{array}$ & EPTC & \begin{tabular}{|l|} 
Chlorpro- \\
pham
\end{tabular} & Alachlor & $\begin{array}{l}\text { Metola- } \\
\text { chlor }\end{array}$ & $\begin{array}{l}\text { Thiobe- } \\
\text { ncarb }\end{array}$ & $\begin{array}{l}\text { Diethofen- } \\
\text { carb }\end{array}$ & $\begin{array}{l}\text { Pendimet- } \\
\text { halin }\end{array}$ & Flutolanil & Lenacil & Fenarimol & Bitertanol \\
\hline \multirow{4}{*}{$\begin{array}{l}\text { Degumming } \\
(5 \mathrm{mg} / \mathrm{kg})\end{array}$} & Use of $85 \%$ & Degummed oil ${ }^{4)}$ & 92.6 & 93.3 & 94.8 & 94.8 & 93.8 & 94.4 & 97.7 & 89.8 & 71.4 & 26.1 & 3.7 \\
\hline & $\mathrm{H}_{3} \mathrm{PO}_{4}(5 \mathrm{~g} / \mathrm{kg})$ & Gum $^{5)}$ & 0.9 & 0.9 & 1.0 & 3.1 & 1.4 & 0.9 & 1.2 & 1.1 & 25.2 & 7.0 & 80.7 \\
\hline & Use of hot & Degummed oil ${ }^{4)}$ & 89.0 & 91.4 & 92.8 & 90.7 & 92.0 & 93.9 & 93.6 & 88.8 & 86.9 & 93.3 & 90.4 \\
\hline & water $(15 \mathrm{~g} / \mathrm{kg})$ & Gum $^{5)}$ & 4.5 & 5.2 & 5.5 & 4.3 & 5.4 & 5.4 & 6.4 & 4.9 & 4.7 & 5.5 & 6.2 \\
\hline \multirow{6}{*}{$\begin{array}{l}\text { Alkali refining } \\
(5 \mathrm{mg} / \mathrm{kg})\end{array}$} & $125 \%$ of $^{2)}$ & Alkali refined oil ${ }^{4}$ & 83.8 & 85.5 & 84.4 & 85.5 & 79.9 & 80.2 & 83.3 & 75.0 & 52.9 & 81.4 & 76.1 \\
\hline & theo & Soapstock ${ }^{5}$ & 3.8 & 8.7 & 9.7 & 7.2 & 7.4 & 8.1 & 9.5 & 7.3 & 24.6 & 13.3 & 12.2 \\
\hline & requirement & Water waste & 3.1 & 3.9 & 4.2 & 2.8 & 3.3 & 3.7 & 4.5 & 3.5 & 10.7 & 5.0 & 5.5 \\
\hline & $200 \%$ of ${ }^{2)}$ & Alkali refined oil ${ }^{4}$ & 81.0 & 82.3 & 80.6 & 79.9 & 75.7 & 74.3 & 76.8 & 73.7 & 47.3 & 72.4 & 70.4 \\
\hline & theoritical & Soapstock ${ }^{5)}$ & 9.6 & 11.7 & 13.2 & 10.4 & 10.1 & 11.1 & 9.4 & 10.3 & 27.7 & 19.4 & 14.9 \\
\hline & & Water waste & 4.7 & 5.5 & 5.8 & 3.9 & 4.8 & 4.9 & 6.5 & 4.9 & 12.0 & 6.9 & 8.0 \\
\hline \multirow{4}{*}{$\begin{array}{l}\text { Bleaching } \\
(5 \mathrm{mg} / \mathrm{kg})\end{array}$} & \multirow{2}{*}{ Activated clay } & Bleache & 90.2 & 95.4 & 23.8 & 65.3 & 94.8 & 70.4 & 94.8 & 83.7 & 41.6 & 4.5 & 0.5 \\
\hline & & Clay waste ${ }^{5)}$ & 4.7 & 4.6 & 2.5 & 16.6 & 5.2 & 21.9 & 5.1 & 10.3 & 57.9 & 36.6 & 31.0 \\
\hline & Activated clay + & Bleached oil ${ }^{4)}$ & 94.7 & 89.9 & 43.1 & 78.9 & 93.0 & 81.4 & 93.2 & 86.0 & 56.8 & 8.0 & 1.3 \\
\hline & larcoal & Clay waste ${ }^{5)}$ & 3.7 & 7.5 & 3.6 & 12.9 & 6.9 & 12.0 & 6.6 & 11.2 & 43.1 & 33.7 & 39.8 \\
\hline \multirow{6}{*}{$\begin{array}{l}\text { Deodorization } \\
(5 \mathrm{mg} / \mathrm{kg})\end{array}$} & \multirow{2}{*}{$160^{\circ} \mathrm{C}^{3)}$} & Deodorized oil $^{4)}$ & 0.0 & 51.1 & 77.3 & 84.3 & 86.1 & 90.8 & 87.5 & 97.3 & 95.8 & 99.1 & 99.1 \\
\hline & & Scum $^{5)}$ & 15.5 & 40.8 & 18.1 & 14.7 & 12.7 & 8.5 & 10.7 & 2.6 & 0.8 & 0.2 & 0.2 \\
\hline & \multirow{2}{*}{$230^{\circ} \mathrm{C}^{3)}$} & Deodorized oil $^{4)}$ & 0.0 & 0.0 & 10.5 & 25.9 & 33.0 & 22.3 & 20.7 & 79.8 & 95.7 & 98.8 & 95.9 \\
\hline & & Scum $^{5)}$ & 0.7 & 79.6 & 73.6 & 62.3 & 51.6 & 61.8 & 70.0 & 10.5 & 2.4 & 0.9 & 0.8 \\
\hline & \multirow{2}{*}{$260^{\circ} \mathrm{C}^{3)}$} & Deodorized oil ${ }^{4)}$ & 0.0 & 0.0 & 0.0 & 0.0 & 0.0 & 0.0 & 0.0 & 1.7 & 17.2 & 51.3 & 50.3 \\
\hline & & Scum $^{5)}$ & 1.2 & 71.7 & 78.5 & 76.1 & 72.5 & 77.8 & 90.0 & 69.4 & 64.9 & 46.0 & 45.0 \\
\hline
\end{tabular}

1) Process condition is shown as Fig. 1

2) Amount of $14 \% \mathrm{NaOH}$ solution

3) Deodorization temperature

4) Residual rate

5) Transfer rate 
率は低くなったが，その他の 8 農薬の減少は緩やかで 60 分後でも $85 \%$ 以上の残存率を示した。30 分後の残存 率を比較すると, 最も残存率の低かった農薬はアラク ロールで $0 \%$, 次いでビテルタノール $44.3 \%$, フェナリ モル 53.4\%で，他の農薬は 85\%以上であった。この実 験結果より農薬及びリン酸の 2 成分相では, アラク ロール，ビテルタノール，フェナリモル，他の農薬の 順で分解されやすいことがわかった。したがって，脱 ガム工程のフェナリモルとビテルタノールの消失はリ ン酸による分解であることが示唆された。しかしなが ら Fig. 2 に見られるように，アラクロールはリン酸と の 2 成分相においては最も分解されたが, リン酸脱ガ 厶工程では残存率が約 95\%とほとんど油脂から除去さ れなかった。リン酸酸性下では, フェナリモルとビテ ルタノールは水溶性であるが, アラクロールは油溶性 である。このためアラクロール及びリン酸の 2 成分相 の場合よりも，さらに油が加わった 3 成分相の場合の 方がアラクロールに対するリン酸の影響が小さかった ものと考えられる。

\section{$3 \cdot 3$ 脱 酸}

まず使用する脱ガム油の酸価を測定し，その脱ガム 油中の遊離脂肪酸を中和するのに要する $14 \%$ 水酸化ナ トリウム溶液の必要量（中和必要量）を求めた。脱酸 はその中和必要量の 1.25 倍量または 2 倍量で処理した。

本工程では, レナシルの残存率が最も低く, 中和必 要量の 1.25 及び 2 倍量添加では, それぞれ 52.9 及び 47.3\%であった。減少量に相当するレナシルはアルカリ フーツ（24.6 及び $27.7 \%)$ 並びに洗浄水（10.7 及び 12.0\%）に移行していた。レナシルはアルカリ性では容

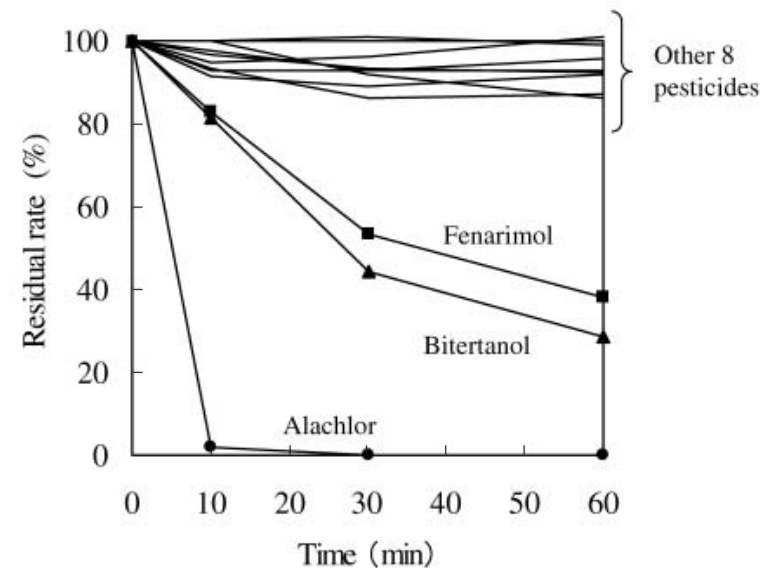

Fig. 2 Stability of Pesticides in Phosphoric Acid. A portion of $2 \mathrm{~mL}$ phosphoric acid was added to 10 ug of 11 each pesticide in a test tube, and the tube was kept at $50^{\circ} \mathrm{C}$.
易に水溶性になるため, 水層に移行しやすくなったも のと考えられる。レナシル以外は農薬の残存率は中和 必要量の 1.25 倍量添加では 75.0 ～85.5\% , 2 倍量添加 では 70.4 ～82.3\%で，アルカリ量の多い方が若干除去 されやすい傾向がみられた。アルカリフーツ, 洗浄水 中の農薬を分析したところ, レナシルの場合と同様に おおむね油脂から除去された量に相当する量が検出さ れた。従って, 除去された農薬は, 分解されずにアル カリフーツ, 洗浄水に移行したことがわかった。

\section{$3 \cdot 4$ 脱 色}

ビテルタノール及びフェナリモルの残存率は, 活性 白土処理及び活性炭含有活性白土処理のいずれの脱色 処理でも $10 \%$ 未満で, 効果的に油脂から除去された。 一方，ほとんど減少しなかった農薬は，クロルプロ ファム, チオベンカルブ, ペンディメタリンで, これ らの残存率は，いずれの処理方法でも $90 \%$ 以上であっ た。他の農薬は 23.8 ～83.7\%の広範囲の残存率を示し， 活性炭の有無による際だった傾向を示さなかった。脱 色工程に打いて有機塩素系（2）及びピレスロイド系 （4）は，顕著な減少は示さなかったが，今回検討した 含窒素系農薬は, 有機リン系（3）に類似して, 農薬ご とにその残存率は大きく異なっていた。

\section{5 脱 臭}

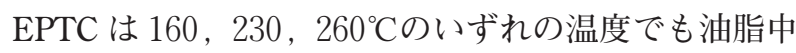
には残存しなかった。他の農薬については, 脱臭温度

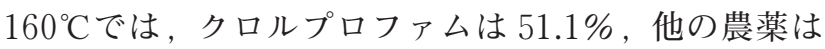

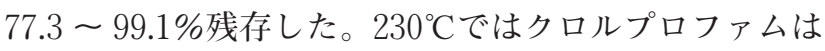
油脂中に残存せず，アラクロール，ペンディメタリン， ジェトフェンカルブ, メトラクロール及びチオベンカ ルブは $10.5 \sim 33.0 \%$ ，フルトラニル，レナシル，ビテ ルタノール及びフェナリモルは $79.8 \%$ 以上残存した。 $260^{\circ} \mathrm{C}$ では, アラクロール, メトラクロール, チオベン カルブ, ジエトフェンカルブ, ペンディベタリンは残 存せず，フルトラニルは $1.7 \%$, レナシルは $17.2 \%$, ビ テルタノール及びフェナリモルはそれぞれ 50.3 及び $51.3 \%$ 残存した。このように農薬は脱臭温度が高いほど 除去されやすくなる傾向を示した。また, 脱臭スカム 中の農薬を分析したところ, 油脂から除去された農薬 の大部分は脱臭スカムに移行していることがわかった。 しかし, EPTC は脱臭スカムからほとんど検出されな かったので, EPTC が水蒸気蒸留中に熱分解や加水分解 したものと推察される。そこで EPTC が $100^{\circ} \mathrm{C}$ 水との 共存下で分解されるのかどうかを検討するため, 次の ような実験を行った。EPTCの $1 \mu \mathrm{g}$ をネジ口ガラス試 験管に採り，水 $2 \mathrm{~mL}$ を加えて密栓し 15 時間加熱した。 加熱温度は試験管の内圧の上昇による破損を防ぐため 
に $100^{\circ} \mathrm{C}$ とした。次いで水水中で冷却後，直ちに酢酸工 チルで試験管内の農薬を抽出し, その残存量を求めと ころ, EPTC は添加した農薬の $100 \%$ が検出された。 従って EPTC は $100^{\circ} \mathrm{C}$ 水との共存下では分解しないこ とが判明した。さらに, EPTCの蒸気圧は他の含窒素系 農薬よりも 1000 倍程度高く（7），非常に揮発しやすい 農薬である。これらのことから, EPTC は脱臭中に分解 したのではなく, 揮散した EPTC が通常の脱臭スカム トラップに抢いては捕集されなかったものと推測した。

\section{$3 \cdot 6$ 総 括}

以上のように，今回検討した農薬はそれぞれの精製 工程で，異なる挙動を示すことがわかった。工程別に 農薬の挙動を概観すると, 9 種類の農薬（EPTC，クロ ルプロファム, アラクロール, メトラクロール, チオ ベンカルブ， ジエトフェンカルブ， ペンディメタリン 及びフルトラニル）は一般に用いられる条件である $260^{\circ} \mathrm{C}$ の脱臭処理（8）で 100\%あるいはほぼ 100\%除去 された。他の 3 種類の農薬（レナシル, フェナリモル 及びビテルタノール） は $260^{\circ} \mathrm{C}$ 脱臭処理でいずれも一 部残存するが，他の 3 工程でも除去されるので 4 工程 を通して精製した場合は，いずれの農薬も大部分油脂 から除去された。そこで, 農薬が原油に $5 \mathrm{ppm}$ 残留し た場合に, 最終製品である食用油脂に残存する農薬量 を各工程の残存率をもとに算出した。精製条件は一般 的な条件のものを採用した。すなわち脱力゙ムは $85 \%$ リ ン酸, 脱酸は中和必要量の 1.25 倍量の水酸化ナトリウ 么, 脱色は活性白土, 脱臭は $260^{\circ} \mathrm{C}$ 条件を用いた。そ の結果, 脱臭後の残存量は, フェナリモルは $0.03 \mathrm{ppm}$, フルトラニルは $0.05 \mathrm{ppm}$, レナシルは $0.14 \mathrm{ppm}$ とな り, 油糧作物の残留基準值（フェナリモル：0.3 ppm, フルトラニル：最低基準值は落花生の $0.5 \mathrm{ppm}$, レナシ ル：0.3 ppm）を下回った。現在, 食用油脂についての 残留基準值は設定されていないが，今回検討した含窒 素系農薬は, 原油にたとえ $5 \mathrm{ppm}$ 程度残留した場合で も，有機塩素系（2）及び有機リン系農薬（3）と同様 に，大部分は検出限界末満に減少することがわかった。 従って, 油糧作物に残留する含窒素系農薬が食品衛生 法の残留基準以下であれば，今回検討した農薬は精製 油脂中にはほとんど残存しないと推察される。

次いで, 市販の食用精製油中の含窒素系農薬を調査 した。試料は国産品 11 銘柄（ゴマ油 3 銘柄, サフラ

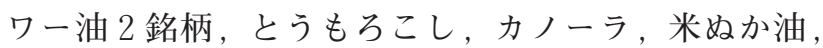

ひまわり油及びアーモンド油各 1 銘柄），輸入品 10 銘 柄（グレープ種子油，落花生油及びオリーブ油各 2 銘 柄，ひまわり油, アーモンド油, くるみ油, 綿実油各 1 銘柄）である。今回検討した 11 種類の含窒素系農薬を 分析したところいずれの銘柄からも検出されなかった。 本研究の要旨は第 43 回日本油化学年会 (平成 16 年 11 月，大阪府吹田市）にて発表した。

謝 辞

本研究にあたりご指導頂いた財団法人 日本食品油脂 検查協会 青山 稔博士, 岡本隆久博士並びに村上千秋博 士に深謝します。

\section{References}

1. K. ROPKINS and A.J. BECK, Application of Hazard Analysis Critical Control Point (HACCP) to Organic Chemical Contaminants in Food, Critical Review in Food Science and Nutrition, Vol. 42, 123-149 (2002).

2. H. KANEMATSU, T. MARUYAMA, I. NIIYA, M. IMAMURA, H. MIZUTANI, Z. MORITA and T. MATSUMOTO, Studies on the Behavior of Trace Components in Oils and Fats during Processing for Edible Use. I. (Removal of Organochlorine Pesticides and Polychlorinated Biphenyls from Oils and Fats by Processing for Edible Use ), Yukagaku, Vol. 25, 38-41 (1976).

3. T. FUKAZAWA, T. TSUTSUMI, S. TOKAIRIN, H. EHARA, T. MARUYAMA and I. NIIYA, Behavior of Organophosphorus Pesticides Obtained from Oils by Refining Treatment, J. Jpn Oil Chem. Soc., Vol. 48, 247-251 (1999).

4. T. FUKAZAWA, M. AOYAMA, T. TSUTSUMI, S. TOKAIRIN, H. EHARA, T. MARUYAMA and I. NIIYA, Behavior of Pyrethroid Pesticides toward Oils during Refining, J. Jpn Oil Chem. Soc., Vol. 48, 885-889 (1999).

5. T. FUKAZAWA, M. AOYAMA, N. SAKURAI, T. TSUTSUMI, S. TOKAIRIN, H. EHARA, T. MARUYAMA and I. NIIYA, Behaviors of Pyrethroid and Organophosphorus Pesticides in Edible Oils during Hydrogenation, J. Oleo Sci., Vol. 51, 29-34 (2002).

6. The Pharmaceutical Society of Japan, Methods of Analysis in Health Science, Kinbara syuppan, pp. 435-441 (2000).

7. Y. UESUGI, M. UEJI and M. KOSHIOKA, Pesticide Data Book, 3rd edn., Soft Science Publications, pp.7, 44, 81, 131, 161, 175, 195, 244, 271, 313, 397 (1997).

8. K. YASUDA, Syokuyou to Sonoseisan, Saiwaishobou, pp.126142 (1992). 